\title{
Nitrous oxide emissions from crop rotations including wheat, oilseed rape and dry peas
}

\author{
M. H. Jeuffroy ${ }^{1,2}$, E. Baranger ${ }^{1,2}$, B. Carrouée ${ }^{3}$, E. de Chezelles ${ }^{1,2}$, M. Gosme ${ }^{1,2}$, C. Hénault ${ }^{4}$, A. Schneider ${ }^{3}$, and \\ P. Cellier ${ }^{5,6}$ \\ ${ }^{1}$ INRA, UMR211 Agronomie, 78850 Thiverval-Grignon, France \\ ${ }^{2}$ AgroParisTech, UMR Agronomie, 78850 Thiverval-Grignon, France \\ ${ }^{3}$ INRA, UR0272 Science du Sol, 2163 Avenue de la Pomme de Pin - CS 40001 ARDON, 45075 Orléans Cedex 2, France \\ ${ }^{4}$ UNIP, 11 rue Monceau, CS 60003, 75378 Paris Cedex 08, France \\ ${ }^{5}$ INRA, UMR1091 Environnement et Grandes Cultures, 78850 Thiverval-Grignon, France \\ ${ }^{6}$ AgroParisTech, UMR Environnement et Grandes Cultures, 78850 Thiverval-Grignon, France
}

Correspondence to: M. H. Jeuffroy (marie-helene.jeuffroy@grignon.inra.fr) and P. Cellier (cellier@grignon.inra.fr)

Received: 1 July 2012 - Published in Biogeosciences Discuss.: 27 July 2012

Revised: 9 February 2013 - Accepted: 11 February 2013 - Published: 18 March 2013

\begin{abstract}
Approximately $65 \%$ of anthropogenic emissions of $\mathrm{N}_{2} \mathrm{O}$, a potent greenhouse gas $(\mathrm{GHG})$, originate from soils at a global scale, and particularly after $\mathrm{N}$ fertilisation of the main crops in Europe. Thanks to their capacity to fix atmospheric $\mathrm{N}_{2}$ through biological fixation, legumes can reduce $\mathrm{N}$ fertilizer use, and possibly $\mathrm{N}_{2} \mathrm{O}$ emissions. Nevertheless, the decomposition of crop organic matter during the crop cycle and residue decomposition, and possibly the $\mathrm{N}$ fixation process itself, could lead to $\mathrm{N}_{2} \mathrm{O}$ emissions. The objective of this study was to quantify $\mathrm{N}_{2} \mathrm{O}$ emissions from a dry pea crop (Pisum sativum, harvested at maturity) and from the subsequent crops in comparison with $\mathrm{N}_{2} \mathrm{O}$ emissions from wheat and oilseed rape crops, fertilized or not, in various rotations. A field experiment was conducted over 4 consecutive years to compare the emissions during the pea crop, in comparison with those during the wheat (fertilized or not) or oilseed rape crops, and after the pea crop, in comparison with other preceding crops. $\mathrm{N}_{2} \mathrm{O}$ fluxes were measured using static chambers. In spite of low $\mathrm{N}_{2} \mathrm{O}$ fluxes, mainly due to the site's soil characteristics, fluxes during the crop were significantly lower for pea and unfertilized wheat than for fertilized wheat and oilseed rape. The effect of the preceding crop was not significant, while soil mineral $\mathrm{N}$ at harvest was higher after the pea crop. These results should be confirmed over a wider range of soil types. Nevertheless, they demonstrate the absence of $\mathrm{N}_{2} \mathrm{O}$ emissions linked to the symbiotic $\mathrm{N}$ fixation process, and allow us to estimate the decrease in $\mathrm{N}_{2} \mathrm{O}$
\end{abstract}

emissions by $20-25 \%$ through including one pea crop in a three-year rotation. On a larger scale, this reduction of GHG emissions at field level has to be added to the decrease due to the reduced production and transport of the $\mathrm{N}$ fertilizer not applied to the pea crop.

\section{Introduction}

$\mathrm{N}_{2} \mathrm{O}$ is a potent greenhouse gas $(\mathrm{GHG})$, which accounts for $6 \%$ of the total anthropogenic radiative forcing (IPCC, 2007). It is also one of the main compounds involved in the ozone layer degradation (Crutzen and Ehhalt, 1977). Its concentration has increased steadily since the end of the 19th century, with more rapid increase in the second half of the 20th century (see e.g. IPCC, 2007; Davidson, 2009). It is widely accepted that microbial production in soils by both nitrification and denitrification is the dominant source of nitrous oxide (Firestone and Davidson, 1989), with a contribution from these two processes to $\mathrm{N}_{2} \mathrm{O}$ emissions varying with weather, soil conditions and soil management (Hénault et al., 1998; Skiba and Smith, 2000). Since the end of the 19 th century, the increased use of nitrogen for human and animal food production, as both synthetic fertilizer and organic manure, has increased $\mathrm{N}_{2} \mathrm{O}$ emissions. At present, approximately $65 \%$ of anthropogenic emissions of $\mathrm{N}_{2} \mathrm{O}$ originate from soils on a global scale (Smith and Dobbie, 2001) and 
in Europe (Leip et al., 2011). But these estimates are still very uncertain and the $\mathrm{N}_{2} \mathrm{O}$ emissions are considered as the most uncertain estimate within the main direct GHG. This is mainly due to large uncertainties in emission factors and this is still under debate (see e.g. Crutzen et al., 2008; Davidson, 2009). Since the agricultural sector contributed more than $20 \%$ of French GHG emissions in 2008 (13.5\% of the global GHG emissions, including $75 \%$ in the developing countries) and since $\mathrm{N}_{2} \mathrm{O}$ represents more than $50 \%$ of the GHG emitted by agriculture (and 12\% of the French part of the GWP, global warming potential), alternative practices to decrease $\mathrm{N}_{2} \mathrm{O}$ emissions are important for mitigating climate change. As $\mathrm{N}_{2} \mathrm{O}$ emissions generally increase with $\mathrm{N}$ input, including, for example, $\mathrm{N}$-fertilisation and residue decomposition, as proposed in the IPCC methodology for fertilized crops, those that do not require $\mathrm{N}$ fertilisation appear as a possible solution to limit $\mathrm{N}_{2} \mathrm{O}$ emissions. Legumes, thanks to their capacity to fix atmospheric $\mathrm{N}_{2}$ through biological nitrogen fixation (BNF), allow a reduction of $\mathrm{N}$ fertilizer use, both on the legume crop and on the following crop as soil mineral $\mathrm{N}$ availability is higher in the year following them (Jensen and Hauggaard-Nielsen, 2003). Using legume crops as a source of nitrogen has thus been envisaged as a solution for decreasing $\mathrm{N}_{2} \mathrm{O}$ emissions, but it is still under debate. In fact legume crops could themselves produce $\mathrm{N}_{2} \mathrm{O}$ by different pathways: (i) during biological $\mathrm{N}_{2}$ fixation itself, (ii) after subsequent $\mathrm{N}$ input from the plant roots to the soil due to rhizodeposition, and (iii) from the decomposition of crop residues and roots after the crop harvest and possible soil incorporation (Zhong et al., 2009). While the latter two might be a $\mathrm{N}_{2} \mathrm{O}$ source as legume tissues have a high $\mathrm{N}$ concentration, the BNF pathway seems less certain (Zhong et al., 2009). Whereas denitrification is known to occur in legume root nodules, the magnitude of this process and its contribution to soil $\mathrm{N}_{2} \mathrm{O}$ emissions could be low compared to $\mathrm{N}_{2} \mathrm{O}$ production by the soil microbial biomass. Hénault and Revellin (2011) showed that $\mathrm{N}_{2} \mathrm{O}$ could even be consumed in legume nodules. Under field conditions large emissions were observed from several legume crops: Duxbury et al. (1982) reported relatively high cumulative fluxes of 2.3 and $4.2 \mathrm{~kg} \mathrm{~N} \mathrm{ha}^{-1} \mathrm{yr}^{-1}$ for an alfalfa field. In contrast, Velthof and Oenema (1997) estimated $\mathrm{N}_{2} \mathrm{O}-\mathrm{N}$ emissions from a grass-clover canopy to vary between 0 and $1 \%$ of biologically fixed $\mathrm{N}_{2}$, probably lower than from an equivalent amount of $\mathrm{N}$ fertilizer because the biologically fixed $\mathrm{N}$ is released slowly into the soil. More recently, Rochette and Janzen (2005) made a synthesis of published studies on $\mathrm{N}_{2} \mathrm{O}$ emissions from legume crops, and concluded that "much of the increase in soil $\mathrm{N}_{2} \mathrm{O}$ emissions in legume crops may be attributable to the $\mathrm{N}$ release from root exudates during the growing season and from decomposition of crop residues after harvest, rather than from biological nitrogen fixation per se". This led them to propose to ignore $\mathrm{N}_{2} \mathrm{O}$ emission from $\mathrm{N}_{2}$ fixation in legume crops, accounting only for $\mathrm{N}$ residue decomposition after the crop. However, this was based mostly on results from soy- bean, grass-legume/clover and alfalfa (Stehfest and Bouwman, 2006) and there are very few references on European annual arable grain legumes grown under European climatic conditions and harvested at maturity (most of the nitrogen being allocated to seeds and not to straw). For example, values for annual legume crops such as peas came from one single paper (Lemke et al., 2007). Moreover, these values were never compared to emissions from other non-leguminous crops grown in the same conditions, although it is known that $\mathrm{N}_{2} \mathrm{O}$ fluxes are highly sensitive to weather and soil conditions (Philibert et al., 2012). Thus, it is difficult to compare the values of $\mathrm{N}_{2} \mathrm{O}$ emissions from legumes, synthesized by Rochette and Janzen (2005), with values from fertilized crops in other experiments, and to draw conclusions about the increase or decrease in $\mathrm{N}_{2} \mathrm{O}$ emissions when legumes are grown instead of fertilized crops. Consequently, more data is needed on emissions from annual legume crops as a component of crop rotations in cropping systems.

The objective of this study was to quantify $\mathrm{N}_{2} \mathrm{O}$ emissions from a pea crop and from the subsequent crops in comparison with $\mathrm{N}_{2} \mathrm{O}$ emissions from wheat and oilseed rape crops, fertilized or not, in various rotations. Our approach was to analyse the different crop stages where $\mathrm{N}_{2} \mathrm{O}$ emissions may arise from $\mathrm{N}_{2}$ fixation, i.e. during and after the legume crop in a crop rotation. We assessed whether the $\mathrm{N}_{2} \mathrm{O}$ emissions during the growth of a dry pea crop were similar to a nonfertilized crop, and whether the $\mathrm{N}_{2} \mathrm{O}$ emissions in autumn following a dry pea crop were higher than following a wheat crop or an oilseed rape crop. Finally, we estimated the extent to which it may be worthwhile to include a legume in a crop rotation.

\section{Materials and methods}

\subsection{Experimental site}

A field trial was conducted at INRA Grignon experimental unit (Paris Basin, $48.9^{\circ} \mathrm{N}, 1.9^{\circ} \mathrm{E}$ ) from 2007 to 2010, combining the comparison of several crops during each year, and the comparison of the effect of several preceding crops on the current crop. The focus was on the pea crop in order to estimate $\mathrm{N}_{2} \mathrm{O}$ emissions during the crop cycle and during the subsequent period (residue decomposition before sowing of the next crop and during the growth of the subsequent crop). The experimental design consisted of 8 treatments (see below) arranged in four randomized blocks, in a 0.19 ha field (Fig. 1). The soil was a clay loam with $25.7 \%$ clay, $66.6 \%$ silt and $7.7 \%$ sand, $1.29 \mathrm{~g} \mathrm{~kg}^{-1}$ total $\mathrm{N}$ and $18 \mathrm{~g} \mathrm{~kg}^{-1}$ organic $\mathrm{C}$. The previous crops were barley (blocks 1 and 2) and wheat (blocks 3 and 4). The soil is not artificially drained but it is deep $(>2 \mathrm{~m}$ ) with a good natural drainage and no evidence of hydromorphy. The soil $\mathrm{P}$ and $\mathrm{K}$ contents were analyzed and found to be above the recommended levels, suggesting that these elements were not limiting for crop growth. Weather 
data were obtained from a meteorological station near the field.

\subsection{Treatments}

Eight different rotations were established in the field to obtain different combinations of three crops (pea, wheat and oilseed rape) and their preceding and succeeding crops (Table 1). A winter wheat crop (cv. Isengrain, 250 seeds $\mathrm{m}^{-2}$ ) was grown after wheat, pea and oilseed rape; a winter oilseed rape (cv. Mendel, 52 seeds $\mathrm{m}^{-2}$ ) crop was grown after wheat or pea; a winter pea crop (cv. Cartouche, 92 seeds $\mathrm{m}^{-2}$ ) was always grown after wheat. Each plot area was $3.5 \mathrm{~m} \times 16.6 \mathrm{~m}$ $\left(58 \mathrm{~m}^{2}\right)$ for the non-fertilized plots, and $5.25 \mathrm{~m} \times 16.6 \mathrm{~m}$ for the fertilized plots $\left(87 \mathrm{~m}^{2}\right)$, arranged in a split plot design, with rotations as main plots and fertilizer levels as sub-plots. The rape and the wheat crops were either fertilized at the optimum rate (using recommended decision support tools) or not fertilized. The pea crop was not fertilized. The sowing dates as well as the dates and amounts of fertilizer application are given in Table 2. The non-fertilized areas were always at the same place from year to year (Fig. 1). Crops were fully protected against weeds and pests by chemical treatments, to prevent growth limitation due to these factors. Each year, crop residues were incorporated and a $20 \mathrm{~cm}$ deep plowing was done before each sowing.

Due to practical limitations, it was not possible to measure $\mathrm{N}_{2} \mathrm{O}$ emissions on all plots every year. Consequently, measurements were made on fertilized wheat $(\mathrm{W})$, fertilized oilseed rape (R), non-fertilized wheat (W0N) and pea $(\mathrm{P})$ on selected rotations in order to take samples over the different crops with the preceding crop including pea or not. The plots on which $\mathrm{N}_{2} \mathrm{O}$ measurements were made are indicated in Table 1. To minimize inter-plot effects, chambers were placed in the middle of each plot, and the plants were sampled outside the two border rows. The chambers were placed on the various treatments all over the trial.

\subsection{Measurements}

$\mathrm{N}_{2} \mathrm{O}$ fluxes were measured using the static closed chamber technique (Hutchinson and Livingston, 1993). Two chambers were set up on each of the three replicates per treatment, i.e. six chambers per treatment in total. The bases of the chamber were installed at the beginning of crop growth over several seeded rows, and were inserted about $5 \mathrm{~cm}$ into the soil. They remained in place during the whole crop life. Care was taken to disturb the soil as little as possible during the installation process. Their internal area was $0.185 \mathrm{~m}^{2}$. Their internal volume was determined by measuring the height above ground of the chambers. It was on average $40 \mathrm{dm}^{3}$ at the beginning of the cycle. When the crop grew, a $60 \mathrm{~cm}$ high extension was added to avoid any damage to the plants. The volume of the chambers increased to approximately $170 \mathrm{dm}^{3}$ afterwards. Measurements were per- formed approximately twice a month, and the frequency was increased to twice a week during the two weeks following fertilizer application. At each date of measurement, all the treatments were measured, whether they received $\mathrm{N}$ fertilizer or not. For each chamber, the air was sampled into a pre-evacuated $10 \mathrm{~mL}$ vial at the closure of the chamber, and $45 \mathrm{~min}, 90 \mathrm{~min}$ and $135 \mathrm{~min}$ afterwards. After sampling, the tubes were analysed in the lab by using a gas chromatograph with an electron-capture detector (Model $3400 \mathrm{Cx}$, Varian, Walnut Creek, USA). On the same days, the soil was sampled in the upper soil layer by taking three soil cores in the 0 $30 \mathrm{~cm}$ layer using an auger in each treatment. The soil samples were mixed together and analysed in order to determine the mineral nitrogen and soil water contents. Soil inorganic $\mathrm{N}$ was determined in a $\mathrm{KCl}\left(1 \mathrm{~mol} \mathrm{~L}^{-1}\right)$ extract with a Skalar Autonalyser, using copper reduction and the Griess-Ilosvay reaction for nitrate and the indophenol method for ammonium. Soil water content was determined by weighing before and after oven drying for $48 \mathrm{~h}$ at $105^{\circ} \mathrm{C}$. Measurements were made during crop growth in spring (from the end of winter in February until harvest) in 2008 (14 measurement dates), 2009 (20 dates) and 2010 (18 dates), and during the autumn (from September until December) in 2008 (8 measurement dates), 2009 (8 dates) and 2010 (5 dates).

At harvest, the amount of $\mathrm{N}$ in the crop residues was measured. Three micro-plots $\left(0.35 \mathrm{~m}^{2}\right.$ each for wheat, $0.875 \mathrm{~m}^{2}$ for pea, and $1 \mathrm{~m}^{2}$ for oilseed rape) per block and per treatment were sampled. Vegetative parts and grains were separated just after sampling and subsequently weighed after oven-drying $\left(48 \mathrm{~h}, 80^{\circ} \mathrm{C}\right)$. Vegetative organs were then ground and $\mathrm{N}$ content was determined with the Dumas method. This involves the combustion of dehydrated and ground plant tissue at about $1800^{\circ} \mathrm{C}$, reduction of nitrogen oxides by reduced $\mathrm{Cu}$ at $600^{\circ} \mathrm{C}$ and analysis of $\mathrm{N}_{2}$ by catharometry (NA 1500 analyser, Fisons Instruments).

After harvest, soil mineral $\mathrm{N}$ content was measured. Three soil cores from each of the three layers $(0-30 \mathrm{~cm}, 30-60 \mathrm{~cm}$, $60-90 \mathrm{~cm}$ ) per block and per treatment were mixed in order to get one sample per layer. Soil inorganic $\mathrm{N}$ content was determined in a $\mathrm{KCl}$ extract with an autoanalyser (Skalar).

\subsection{Statistical analysis}

Mixed models were fitted to the data in order to analyse the effects of the crop and the preceding crops (considered as fixed effects), and taking into account the effects of block and date of measurement (considered as random effects). As nitrogen fertilizer application may interfere with $\mathrm{N}_{2} \mathrm{O}$ emission, the crop cycle was divided into 3 periods: (i) before the first $\mathrm{N}$ application of the season (before Napp) including the autumn dates of measurement, (ii) more than 14 days after the last $\mathrm{N}$ fertilizer application (after Napp), and (iii) between these two dates (following Napp). The same period distinction was applied for all crops during each cropping season. The period was included in the mixed model as a fixed effect, 


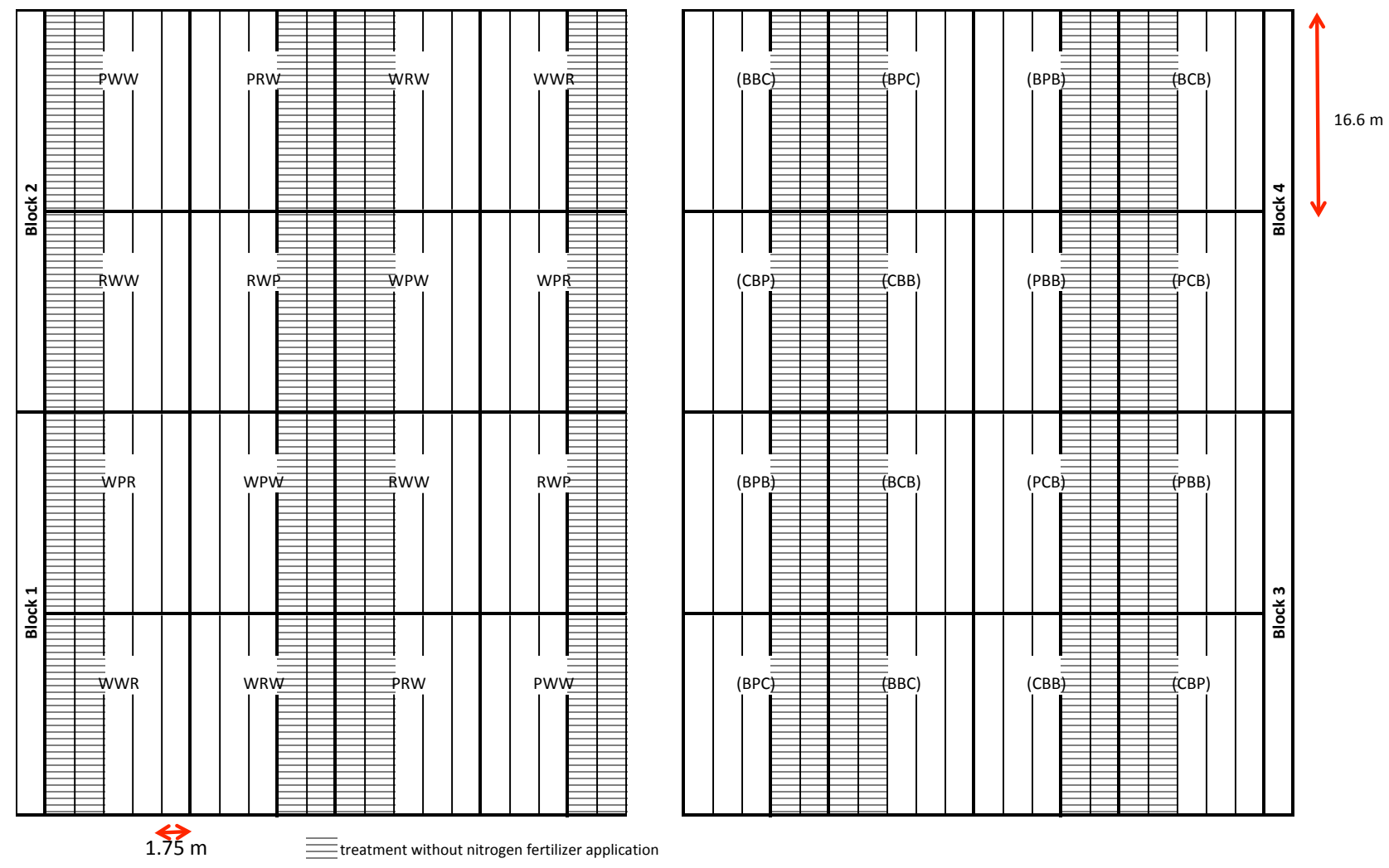

Fig. 1. Map of the trial.

Table 1. Crop sequences in the field trial over the five years (first column, $\mathrm{W}=$ winter wheat; $\mathrm{R}=$ rape; $\mathrm{P}=$ pea).

\begin{tabular}{|c|c|c|c|c|c|c|}
\hline No & Rotation & 2006-2007 & 2007-2008 & 2008-2009 & 2009-2010 & 2010-2011 \\
\hline 1 & WRW & & Winter wheat ${ }^{\mathrm{a}, \mathrm{b}}$ & Oilseed rape $\mathrm{a}^{\mathrm{a}}$ & Winter wheat & Winter wheat \\
\hline 2 & WPR & & Winter wheat ${ }^{\mathrm{a}, \mathrm{b}}$ & Winter pea & Oilseed rape $\mathrm{a}^{\mathrm{a}}$ & Winter wheat \\
\hline 3 & WPW & Winter wheat & Winter wheat & Winter pea ${ }^{a}$ & Winter wheat & Winter wheat \\
\hline 4 & WWR & (blocks 3 and 4) & Winter wheat ${ }^{a, b}$ & Winter wheat & Oilseed rape $\mathrm{a}^{\mathrm{a}}$ & Winter wheat ${ }^{\mathrm{a}, \mathrm{b}}$ \\
\hline 5 & RWW & and winter & Oilseed rape $\mathrm{a}^{\mathrm{a}}$ & Winter wheat ${ }^{\mathrm{a}}$ & Winterwheat & Winter wheat \\
\hline 6 & RWP & barley (blocks & Oilseed rape $\mathrm{a}^{\mathrm{a}}$ & Winter wheat & Winter pea ${ }^{a}$ & Winter wheat ${ }^{\text {a }}$ \\
\hline 7 & PRW & 1 and 2) & Winter pea ${ }^{\mathrm{a}}$ & Oilseed rape $\mathrm{a}^{\mathrm{a}}$ & Winter wheat ${ }^{\mathrm{a}}$ & Winter wheat \\
\hline 8 & PWW & & Winter pea ${ }^{a}$ & Winter wheat ${ }^{\mathrm{a}, \mathrm{b}}$ & Winter wheat ${ }^{\mathrm{a}, \mathrm{b}}$ & Winter wheat ${ }^{\mathrm{a}, \mathrm{b}}$ \\
\hline
\end{tabular}

a Treatments with $\mathrm{N}_{2} \mathrm{O}$ emission measurements.

b Measurement of $\mathrm{N}_{2} \mathrm{O}$ emissions also on the non-fertilized treatment.

as well as the two-way interactions between period and crop and preceding crop, respectively. Each effect was tested by comparing the same models with and without the considered effect with a likelihood ratio test. In the case of significant interactions, a new factor was created by taking the combination of the two interacting factors (e.g. crop_period). When the effect was not significant, it was removed from the model. In the case of significant effects, multiple comparisons with Tukey contrasts were performed in order to compare the treatments.
In order to study the effect of crop residues in more detail, a further analysis was done on the mean $\mathrm{N}_{2} \mathrm{O}$ emissions during autumn (from the beginning of September until the end of December) for each year, because we assumed that during this period, the effect of the current crop had not yet appeared, and that the $\mathrm{N}_{2} \mathrm{O}$ emissions associated with the crop resulted mainly from residue decomposition. The preceding crop was considered as a fixed effect and the year and block as random effects.

We also analysed the effect of the crop and the preceding crop on the soil mineral nitrogen content measured after 

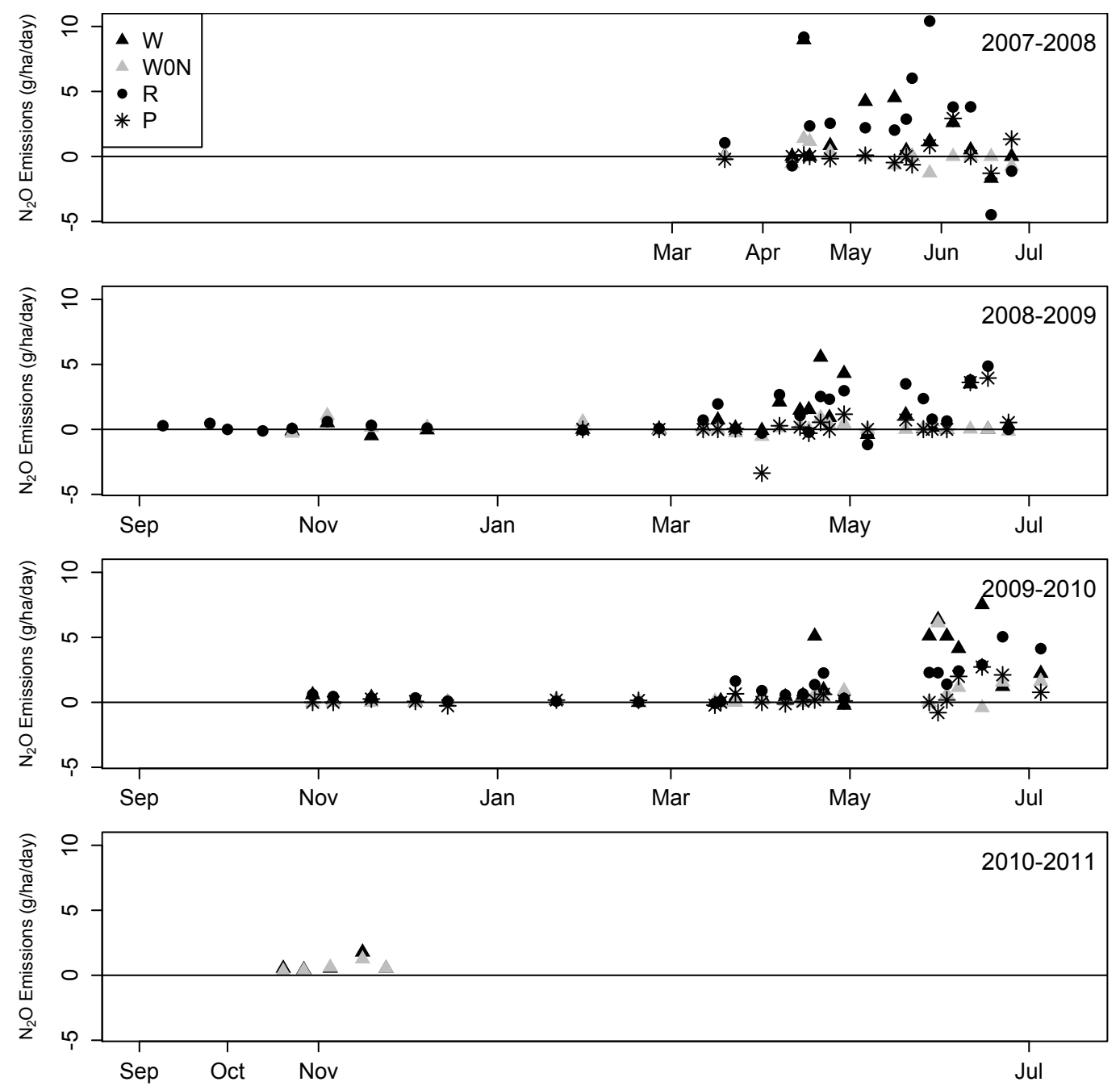

Fig. 2. Mean $\mathrm{N}_{2} \mathrm{O}$ fluxes (mean over all blocks and preceding crops) against date for the different crops $(\mathrm{W}=$ wheat, W0N $=$ unfertilized wheat, $\mathrm{R}=$ rape, $\mathrm{P}=$ pea) for each cropping season $\left(\mathrm{g} \mathrm{N}-\mathrm{N}_{2} \mathrm{O} \mathrm{ha}^{-1} \mathrm{day}^{-1}\right)$. Dates of fertilization have not been included in the figure as they vary according to the crop and preceding crop.

harvest, and on the amount of $\mathrm{N}$ present in the crop residues at harvest, as both variables represent sources of $\mathrm{N}_{2} \mathrm{O}$ emission which must be considered according to the IPCC guidelines (IPCC, 2006). The same approach was taken, starting from a model including crop and preceding crop as fixed effects, and year and block as random effects, on the amount of nitrogen contained in the crop residues remaining on the ground after harvest, or on the amount of soil mineral nitrogen content measured at harvest.

All analyses were performed using R statistical software, with packages lme4 (Bates and Maechler, 2009) for the mixed models and multcomp (Hothorn et al., 2008) for the multiple comparison tests. The assumptions of the linear mixed model were checked by visual examination of the plot of residuals against predicted values and qqplots for the residuals and the random effects.

\section{Results}

\subsection{Measured $\mathrm{N}_{2} \mathrm{O}$ fluxes}

$\mathrm{N}_{2} \mathrm{O}$ emissions measured during the four cropping seasons on the four crops are presented in Fig. 2 for both the autumn and spring periods. The measured fluxes were relatively low, ranging between -4 and $10 \mathrm{~g} \mathrm{ha}^{-1} \mathrm{day}^{-1}$ with negative fluxes at several periods. They show a high variability of $\mathrm{N}_{2} \mathrm{O}$ emissions on fertilized wheat and rape throughout the crop cycle. Despite low values, significant differences can be observed between crops, with fertilized wheat and rapeseed having larger fluxes than unfertilized wheat and peas, especially after fertilizer application. The maximum fluxes were not always observed just after fertilizer application but sometimes 2-3 weeks later. $\mathrm{N}_{2} \mathrm{O}$ emission during autumn 
Table 2. Sowing and harvest dates of each crop, total rate, dates and rates of nitrogen fertilizer applied on each crop according to each rotation.

\begin{tabular}{|c|c|c|c|c|c|c|c|c|c|}
\hline \multirow{2}{*}{ No } & \multirow{2}{*}{ Rotation } & \multirow{2}{*}{ Year } & \multirow{2}{*}{ Crop } & \multirow{2}{*}{ Sowing date } & \multirow{2}{*}{ Harvest date } & \multicolumn{4}{|c|}{ Fertilisation: amount in $\mathrm{kg} \mathrm{Nha}^{-1}$ (date) } \\
\hline & & & & & & Total & 1st appl. & 2nd appl. & 3rd appl. \\
\hline \multirow{3}{*}{1} & \multirow{3}{*}{ WRW } & $2007-2008$ & $\mathrm{~W}$ & 12 Oct & $16 \mathrm{Jul}$ & 220 & $50(19 \mathrm{Feb})$ & 130 (9 Apr) & 40 (9 May) \\
\hline & & 2008-2009 & $\mathrm{R}$ & 4 Sep & $7 \mathrm{Jul}$ & 200 & 60 (13 Mar $)$ & 140 (9 Apr) & - \\
\hline & & 2009-2010 & $\mathrm{W}$ & $28 \mathrm{Oct}$ & $21 \mathrm{Jul}$ & 150 & $50(10 \mathrm{Mar})$ & $60(12 \mathrm{Apr})$ & 40 (14 May) \\
\hline \multirow{3}{*}{2} & \multirow{3}{*}{ WPR } & 2007-2008 & $\mathrm{W}$ & $12 \mathrm{Oct}$ & $16 \mathrm{Jul}$ & 220 & $50(19 \mathrm{Feb})$ & 130 (9 Apr) & 40 (9 May) \\
\hline & & 2008-2009 & $\mathrm{P}$ & $20 \mathrm{Nov}$ & $6 \mathrm{Jul}$ & 0 & - & - & - \\
\hline & & 2009-2010 & $\mathrm{R}$ & 8 Sep & $16 \mathrm{Jul}$ & 110 & $60(10 \mathrm{Mar})$ & $50(12 \mathrm{Apr})$ & - \\
\hline \multirow{3}{*}{3} & \multirow{3}{*}{ WPW } & $2007-2008$ & $\mathrm{~W}$ & $12 \mathrm{Oct}$ & $16 \mathrm{Jul}$ & 220 & $50(19 \mathrm{Feb})$ & 130 (9 Apr) & 40 (9 May) \\
\hline & & 2008-2009 & $\mathrm{P}$ & $20 \mathrm{Nov}$ & $6 \mathrm{Jul}$ & 0 & - & - & - \\
\hline & & $2009-2010$ & $\mathrm{~W}$ & 28 Oct & $21 \mathrm{Jul}$ & 160 & $50(10 \mathrm{Mar})$ & $70(12 \mathrm{Apr})$ & 40 (14 May) \\
\hline \multirow{3}{*}{4} & \multirow{3}{*}{ WWR } & 2007-2008 & $\mathrm{W}$ & $12 \mathrm{Oct}$ & $16 \mathrm{Jul}$ & 220 & $50(19 \mathrm{Feb})$ & 130 (9 Apr) & 40 (9 May) \\
\hline & & 2008-2009 & $\mathrm{W}$ & 20 Oct & $16 \mathrm{Jul}$ & 160 & 50 (13 Mar $)$ & 70 (9 Apr) & 40 (18 May) \\
\hline & & 2009-2010 & $\mathrm{R}$ & 8 Sep & $16 \mathrm{Jul}$ & 115 & $60(10 \mathrm{Mar})$ & $55(12 \mathrm{Apr})$ & - \\
\hline \multirow{3}{*}{5} & \multirow{3}{*}{ RWW } & $2007-2008$ & $\mathrm{R}$ & $19 \mathrm{Sep}$ & 30 Jun & 170 & $50(19 \mathrm{Feb})$ & 120 (9 Apr) & - \\
\hline & & 2008-2009 & $\mathrm{W}$ & $20 \mathrm{Oct}$ & $16 \mathrm{Jul}$ & 160 & 50 (13 Mar $)$ & $70(9 \mathrm{Apr})$ & 40 (18 May) \\
\hline & & 2009-2010 & $\mathrm{W}$ & $28 \mathrm{Oct}$ & $21 \mathrm{Jul}$ & 220 & $50(10 \mathrm{Mar})$ & $130(12 \mathrm{Apr})$ & 40 (14 May) \\
\hline \multirow{3}{*}{6} & \multirow{3}{*}{ RWP } & $2007-2008$ & $\mathrm{R}$ & $19 \mathrm{Sep}$ & 30 Jun & 170 & $50(19 \mathrm{Feb})$ & $120(9 \mathrm{Apr})$ & - \\
\hline & & 2008-2009 & $\mathrm{W}$ & $20 \mathrm{Oct}$ & $16 \mathrm{Jul}$ & 160 & 50 (13 Mar $)$ & 70 (9 Apr) & 40 (18 May) \\
\hline & & 2009-2010 & $\mathrm{P}$ & 29 Oct & $2 \mathrm{Jul}$ & 0 & - & - & - \\
\hline \multirow{3}{*}{7} & \multirow{3}{*}{ PRW } & $2007-2008$ & $\mathrm{P}$ & $12 \mathrm{Nov}$ & 30 Jun & 0 & - & - & - \\
\hline & & 2008-2009 & $\mathrm{R}$ & $4 \mathrm{Sep}$ & $7 \mathrm{Jul}$ & 160 & 60 (13 Mar $)$ & $100(9$ Apr $)$ & - \\
\hline & & 2009-2010 & W & $28 \mathrm{Oct}$ & $21 \mathrm{Jul}$ & 170 & 50 (10 Mar $)$ & $80(12 \mathrm{Apr})$ & 40 (14 May) \\
\hline \multirow{3}{*}{8} & \multirow{3}{*}{ PWW } & 2007-2008 & $\mathrm{P}$ & $12 \mathrm{Nov}$ & 30 Jun & 0 & - & - & - \\
\hline & & 2008-2009 & $\mathrm{W}$ & $20 \mathrm{Oct}$ & $16 \mathrm{Jul}$ & 160 & $50(13$ Mar $)$ & 70 (9 Apr) & 40 (18 May) \\
\hline & & 2009-2010 & $\mathrm{W}$ & $28 \mathrm{Oct}$ & $21 \mathrm{Jul}$ & 220 & 50 (10 Mar) & $130(12 \mathrm{Apr})$ & 40 (14 May) \\
\hline
\end{tabular}

was even lower, around $\pm 1 \mathrm{~g} \mathrm{ha}^{-1} \mathrm{day}^{-1}$. The same trends were observed during the three years.

\subsection{Effect of crops and preceding crops on $\mathrm{N}_{2} \mathrm{O}$ emissions}

The comparison of the mixed models for $\mathrm{N}_{2} \mathrm{O}$ emissions showed significant date and block random effects $(p<0.001$ and $p=0.008$, respectively). The interaction between preceding crop and period of measurement was not significant $(p=0.8)$ and was thus removed from the model. The interaction crop $\times$ period was highly significant $(p<0.001)$, indicating that $\mathrm{N}_{2} \mathrm{O}$ emissions varied during crop growth differently according to the crop. Consequently, the analysis was carried out on the combinations of crop $\times$ period (i.e. on a new variable crop_period). The results then showed that there was no effect of the preceding crop $(p=0.48)$ but a highly significant crop_period effect $(p<0.001)$. The multiple comparison tests showed that for the fertilized crops, emissions were higher after $\mathrm{N}$ fertilisation than before, with intermediate values during the period of $\mathrm{N}$ application
(Fig. 3). For non-fertilized crops (W0N and P), emissions were not significantly different between the three periods.

As preceding crop had no significant effect, mean daily fluxes were calculated for each crop during the two complete cropping seasons, 2008-2009 and 2009-2010, whatever the preceding crop. Average values were $0.91 \mathrm{~g} \mathrm{ha}^{-1} \mathrm{day}^{-1}$ and $1.77 \mathrm{~g} \mathrm{ha}^{-1} \mathrm{day}^{-1}$ for wheat, $1.09 \mathrm{~g} \mathrm{ha}^{-1} \mathrm{day}^{-1}$ and $1.30 \mathrm{~g} \mathrm{ha}^{-1} \mathrm{day}^{-1}$ for rape, $0.37 \mathrm{~g} \mathrm{ha}^{-1} \mathrm{day}^{-1}$ and $0.38 \mathrm{~g} \mathrm{ha}^{-1} \mathrm{day}^{-1}$ for pea, $0.14 \mathrm{~g} \mathrm{ha}^{-1} \mathrm{day}^{-1}$ and $0.57 \mathrm{~g} \mathrm{ha}^{-1} \mathrm{day}^{-1}$ for non-fertilized wheat, during 2008 2009 and 2009-2010, respectively.

\subsection{Effects of crop residues on $\mathrm{N}_{2} \mathrm{O}$ emissions during autumn}

When the mean $\mathrm{N}_{2} \mathrm{O}$ emissions during autumn of each year were analysed separately, there was a significant (random) year effect $(p<0.001)$ but no significant effect of block $(p=0.38)$. There was also no significant effect of the type of residues (i.e. preceding crop) $(p=0.49)$. Figure 4 shows 


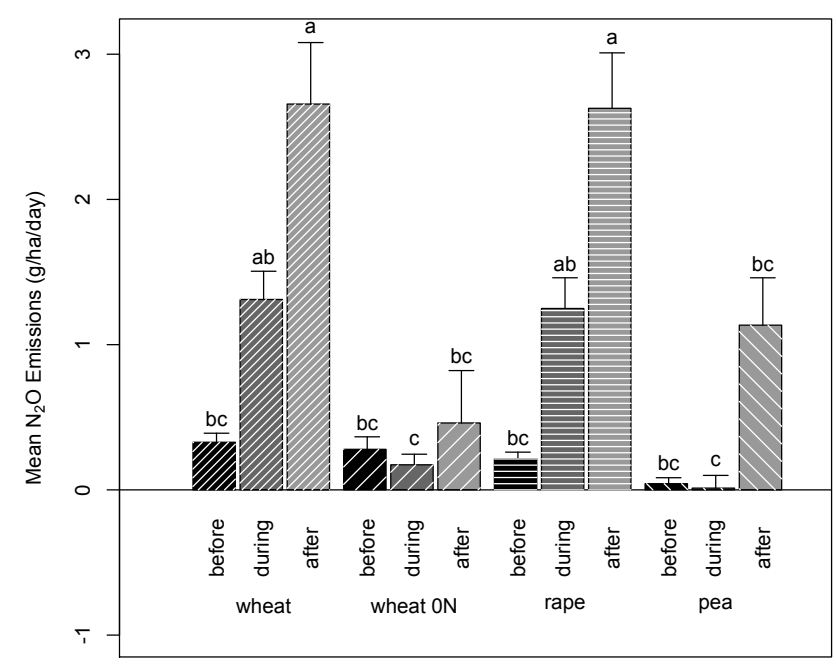

Fig. 3. Mean $\mathrm{N}_{2} \mathrm{O}$ emissions $\left(\mathrm{g} \mathrm{N}^{-\mathrm{N}_{2}} \mathrm{Oha}^{-1}\right.$ day $\left.^{-1}\right)$ as a function of the crop (wheat, winter rape or pea), fertilized or not $(0 \mathrm{~N})$ and period of observation (before the first $\mathrm{N}$ fertilisation, more than 14 days after the last $\mathrm{N}$ fertiliser or during the period of $\mathrm{N}$ fertilization). Bars with the same letter are not significantly different. Error bars $=$ standard error of the mean.

the mean emissions during autumn for the different preceding crops and years.

\subsection{Soil mineral $\mathbf{N}$ content after harvest}

Figure 5 and Table 3 show the mineral $\mathrm{N}$ content in soil after harvest of each crop during each year. Values varied greatly according to the crop and, to a lesser extent, the year. The comparison of the mixed models showed a significant effect of the year $(p=0.035)$ but no block effect $(p=1)$. There was no effect of the preceding crop $(p=0.17)$ but a highly significant effect of the crop $(p<0.0001)$. The multiple comparisons showed that soil mineral content after harvest was lower for oilseed rape and unfertilized wheat than for fertilized wheat and peas (Fig. 5), although this difference was not significant.

\subsection{N content in crop residues at harvest}

The $\mathrm{N}$ contents in crop residues at harvest varied greatly according to the year and the crop. The comparison of the mixed models showed significant year and block effects $(p<$ 0.0001 and $p=0.0023$, respectively). There was a significant effect on the preceding crop $(p=0.003)$ as well as on the current crop ( $p<0.0001$; Fig. 6$)$. The multiple comparisons showed that the crop effect was only due to the difference between the residues of unfertilized wheat or oilseed rape and peas, fertilized wheat or oilseed rape, and the effect of the preceding crop is only visible through the significant difference between unfertilized wheat after unfertilized wheat and unfertilized wheat after peas (Fig. 6).

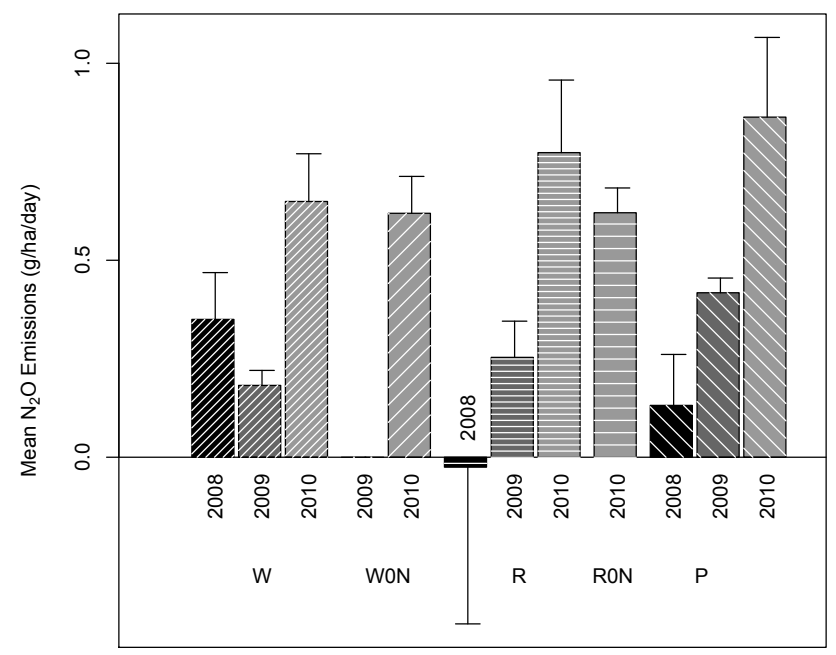

Fig. 4. Mean $\mathrm{N}_{2} \mathrm{O}$ emissions ( $\mathrm{g} \mathrm{N}-\mathrm{N}_{2} \mathrm{O} \mathrm{ha}^{-1}$ day $^{-1}$ ) during autumn as a function of the preceding $\operatorname{crop}(\mathrm{W}=$ Wheat, $\mathrm{R}=\mathrm{Rape}, \mathrm{P}=\mathrm{Pea}$, $\mathrm{W} 0 \mathrm{~N}=$ unfertilized wheat) and year. Error bars $=$ standard error of the mean.

\section{Discussion}

The results of these experiments provide new information on nitrous oxide emissions in a pea crop. They are discussed below from different points of view. First at process level, we discuss the observed variability in emissions, its origin and the processes involved. Secondly, at crop level, we compare the emissions from the pea crop and from the other crops, fertilized or not, and finally we use these results to assess GHG budgets over different crops and rotations.

\section{1 $\quad \mathrm{N}_{2} \mathrm{O}$ emission variability}

As a whole, $\mathrm{N}_{2} \mathrm{O}$ emissions were low for all crops on the Grignon field site, with background emission less than $1 \mathrm{~g} \mathrm{ha}^{-1} \mathrm{day}^{-1}$ and averages after fertilization between 2 and $3 \mathrm{~g} \mathrm{ha}^{-1} \mathrm{day}^{-1}$. Most values were below $10 \mathrm{gha}^{-1} \mathrm{day}^{-1}$. Consequently, the total emissions over the crop's life were relatively low, with little variability between years (Fig. 2). We observed a general increase in the $\mathrm{N}_{2} \mathrm{O}$ emission as a function of temperature, rainfall and soil water content, though with large variability (data not shown). Loubet et al. (2011) and Laville et al. (2011) observed similar fluxes over a nearby site with similar soil conditions and agricultural practices, using automated chambers with continuous measurements (16 values per day). However, they also observed much larger fluxes under three circumstances: in summer 2007 after a barley harvest and residue incorporation, in December 2007 after a low temperature period, and in May 2008 after $\mathrm{N}$ application to maize. In the first case, the summer was cooler than average but much wetter, which certainly favored $\mathrm{N}_{2} \mathrm{O}$ emission from residue decomposition. High emissions in May 2008 were 


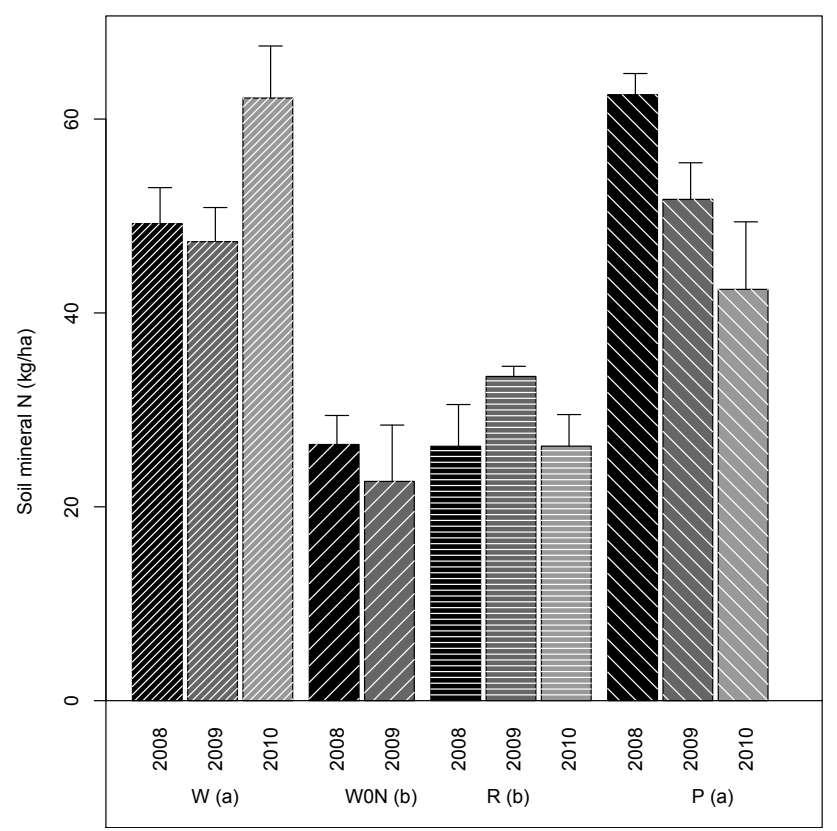

Fig. 5. Soil mineral content $\left(\mathrm{kg} \mathrm{ha}^{-1}\right)$ after harvest in the whole soil profile according to the crop (which was just harvested: $\mathrm{W}=$ wheat, $\mathrm{W} 0 \mathrm{~N}=$ unfertilized wheat, $\mathrm{R}=$ rape, $\mathrm{P}=$ pea) and the year. Groups of bars with the same letter are not significantly different. Error bars: standard error of the mean.

attributable to the combination of high rates of maize $\mathrm{N}$ fertilization $\left(130 \mathrm{~kg} \mathrm{Nha}^{-1}\right.$ as ammonium nitrate following $107 \mathrm{~kg} \mathrm{~N} \mathrm{ha}^{-1}$ as slurry), high temperature (monthly average almost $2{ }^{\circ} \mathrm{C}$ above the long-term mean) and higher than average rainfall. This was not observed on our plots because of limited $\mathrm{N}$ availability due to low inputs at this period to the investigated crops (Table 2). But the main reason for the low emissions observed during the $3 \mathrm{yr}$ could be the low rainfall which occurred throughout the year $(458,388$ and $406 \mathrm{~mm}$ during the cropping period, from October until June, respectively, in 2008, 2009 and 2010) and especially during the period of fertilizer application in 2009 and 2010, when rainfall was much lower (71 and $48 \mathrm{~mm}$, respectively) than the average for this site $(89 \mathrm{~mm})$, with only 4 days with rainfall greater than $2 \mathrm{~mm} \mathrm{day}^{-1}$ in $2009\left(\max =6.2 \mathrm{~mm} \mathrm{day}^{-1}\right)$ and $2010\left(\max =3.5 \mathrm{~mm} \mathrm{day}^{-1}\right)$. The last reason might be that, due to their low measurement frequency (two measurements per week or per month), the manual chamber did not record the $\mathrm{N}_{2} \mathrm{O}$ emission pulses which contribute significantly to the annual emissions. For instance, Parkin (2008) estimated that sampling at time intervals of more than one week could lead to underestimating cumulative fluxes by approx. $30 \%$, while Smith and Dobbie (2001) and Laville et al. (2011) estimated that the bias was less than $15 \%$.

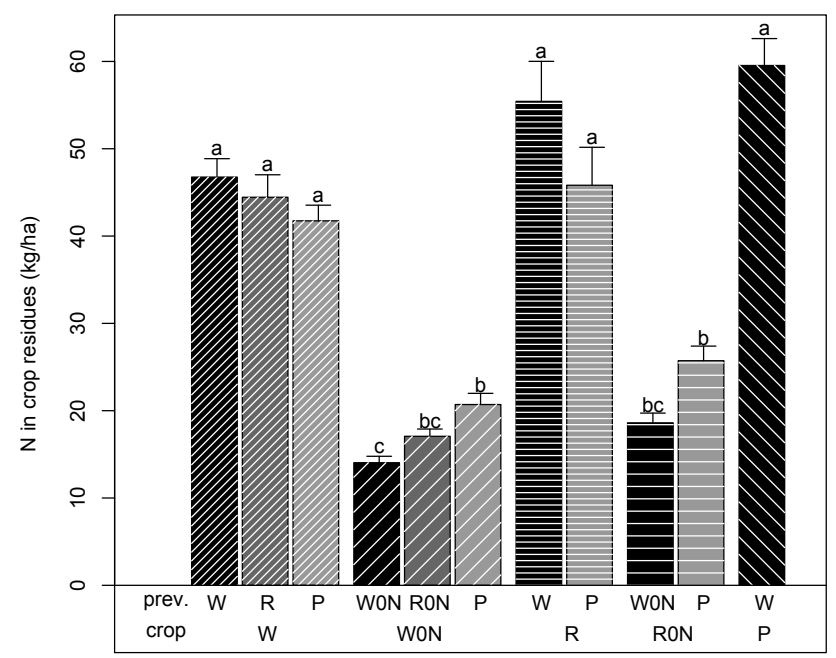

Fig. 6. $\mathrm{N}$ in crop residues $\left(\mathrm{kg} \mathrm{ha}^{-1}\right)$ at harvest according to the crop and the previous crop. Bars with the same letter are not significantly different. Error bars: standard error of the mean.

As expected, a clear effect of fertilization was observed, with emissions five to tenfold larger than background emissions during the weeks following fertilizer application (Fig. 3). However a surprising feature was that emissions were maximum two weeks after $\mathrm{N}$ application. Once again, this might be attributed to the relatively dry conditions. Le Cadre (2004) observed that pellet dissolution, which is necessary to make $\mathrm{N}$ available to the soil, and thus to nitrification or denitrification, may take more than 10 days under dry soil conditions. Moreover, soil microorganisms might be relatively inactive in the top soil layers under such situations.

\section{2 $\mathrm{N}_{2} \mathrm{O}$ emissions from the pea crop and processes involved}

Despite such low fluxes, significant differences were observed both between crops and between periods, attributable to fertilization events (Fig. 3) for the three years of the experiments. The robustness of this observation was strengthened by the experimental design (randomized blocks) and the methods used for statistical analysis. It can therefore be assumed that, even if the cumulative fluxes are biased due to low observation frequency, the relative differences, and hence the effects, can be viewed with confidence.

On the other hand, no effect of the preceding crop was observed on $\mathrm{N}_{2} \mathrm{O}$ fluxes, either for the entire growth period or just during the autumn. This result was observed in all three years. It casts doubt on the suggestion that $\mathrm{N}_{2} \mathrm{O}$ emissions in legumes might be higher than for other crops during the decomposition of their residues after harvest, due to their higher $\mathrm{N}$ concentration (Rochette and Janzen, 2005). It is consistent with previous results from Lemke et al. (2002), who did not find significantly higher $\mathrm{N}_{2} \mathrm{O}$ emissions after a pea crop than after a wheat crop. Our result is also consistent with 
Table 3. Total cropping year emissions data for each treatment and each year (first column, $\mathrm{W}=$ winter wheat; $\mathrm{R}=\mathrm{rape} ; \mathrm{P}=$ pea):

\begin{tabular}{|c|c|c|c|c|c|}
\hline No & Rotation & Year & Crop & $\begin{array}{r}\text { Total } \mathrm{N}_{2} \mathrm{O} \text { emissions } \\
\text { from sowing to } \\
\text { harvest of the crop } \\
\text { (cumulative } \mathrm{g} \mathrm{ha}^{-1} \text { ) }\end{array}$ & $\begin{array}{r}\text { Soil mineral N } \\
\text { after harvest } \\
\left(\mathrm{kg} \mathrm{N} \mathrm{ha}^{-1}\right) \text { in } \\
0-90 \mathrm{~cm} \text { soil depth }\end{array}$ \\
\hline \multirow{4}{*}{1} & \multirow{4}{*}{ WRW } & \multirow{2}{*}{ 2007-2008 } & $\mathrm{W}$ & 434 & 49 \\
\hline & & & W0 & -5 & 26 \\
\hline & & 2008-2009 & $\mathrm{R}$ & 314 & 32 \\
\hline & & 2009-2010 & $\mathrm{W}$ & n.m. & 53 \\
\hline \multirow{3}{*}{2} & \multirow{3}{*}{ WPR } & 2007-2008 & W & 434 & 49 \\
\hline & & 2008-2009 & $\mathrm{P}$ & 84 & 52 \\
\hline & & 2009-2010 & $\mathrm{R}$ & 377 & 25 \\
\hline \multirow{3}{*}{3} & \multirow{3}{*}{ WPW } & 2007-2008 & W & 434 & 49 \\
\hline & & 2008-2009 & $\mathrm{P}$ & 84 & 52 \\
\hline & & 2009-2010 & W & n.m. & 56 \\
\hline \multirow{3}{*}{4} & \multirow{3}{*}{ WWR } & 2007-2008 & $\mathrm{W}$ & 434 & 49 \\
\hline & & 2008-2009 & $\mathrm{W}$ & n.m. & 56 \\
\hline & & 2009-2010 & $\mathrm{R}$ & 435 & 27 \\
\hline \multirow{3}{*}{5} & \multirow{3}{*}{ RWW } & 2007-2008 & $\mathrm{R}$ & 864 & 26 \\
\hline & & 2008-2009 & W & 271 & 43 \\
\hline & & 2009-2010 & $\mathrm{W}$ & n.m. & 79 \\
\hline \multirow{3}{*}{6} & \multirow{3}{*}{ RWP } & 2007-2008 & $\mathrm{R}$ & 864 & 26 \\
\hline & & 2008-2009 & W & 271 & 43 \\
\hline & & 2009-2010 & $\mathrm{P}$ & 93 & 42 \\
\hline \multirow{3}{*}{7} & \multirow{3}{*}{ PRW } & 2007-2008 & $\mathrm{P}$ & 43 & 62 \\
\hline & & 2008-2009 & $\mathrm{R}$ & 352 & 34 \\
\hline & & 2009-2010 & W & 181 & 53 \\
\hline \multirow{5}{*}{8} & \multirow{5}{*}{ PWW } & 2007-2008 & $\mathrm{P}$ & 43 & 62 \\
\hline & & \multirow{2}{*}{ 2008-2009 } & $\mathrm{W}$ & 217 & 44 \\
\hline & & & W0 & 39 & 23 \\
\hline & & \multirow{2}{*}{ 2009-2010 } & $\mathrm{W}$ & 490 & 69 \\
\hline & & & W0 & 152 & n.m. \\
\hline
\end{tabular}

n.m. = not measured

the observations on the possible sources of nitrogen for $\mathrm{N}_{2} \mathrm{O}$ emissions: soil mineral nitrogen after harvest was not higher after peas than after wheat, and total $\mathrm{N}$ in crop residues was not significantly different between peas and fertilized rape or wheat. In contrast, Hauggaard-Nielsen et al. (2003) found significantly more $\mathrm{N}\left(\mathrm{kg} \mathrm{ha}^{-1}\right)$ in pea straw than in barley straw. More data are needed to confirm this result.

Concerning the amount of $\mathrm{N}$ in pea residues, it should be noted that this experiment involved a dry pea crop. Vining peas (or garden peas) are the same botanical species but are harvested at an earlier stage, before the translocation of $\mathrm{N}$ from the leaves to the seeds. Consequently, the total $\mathrm{N}$ amount of vining pea residues and their $\mathrm{N} / \mathrm{C}$ ratio are significantly higher than for dry pea or wheat residues (Carrouée et al., 2006): different results for $\mathrm{N}$ mineralization and possibly $\mathrm{N}_{2} \mathrm{O}$ emissions could then be observed. The references in the literature dealing with the "pea crop" do not always state clearly which type of pea is concerned, and so should be treated with caution.

\subsection{Comparison of $\mathrm{N}_{2} \mathrm{O}$ emissions from peas and other crops}

Our results clearly show the lower emissions from the pea crop than from the fertilized wheat or oilseed rape, with an average ratio of $1: 4$ to $1: 6$, respectively, over the growing season for the three years, and a range of $1: 3$ to $1: 12$ over the years (Table 3 ). They were not significantly different from those of the unfertilized wheat crop. Moreover, these results were observed in all three years. The cumulative fluxes were no greater than emissions from natural vegetation as estimated by Stehfest and Bouwmann (2006). They are in the low range of $\mathrm{N}_{2} \mathrm{O}$ emissions from legumes, as published in the synthesis by Rochette and Janzen (2005). 
They are even lower than the values given by Lemke et al. (2007), which is the only reference for a pea crop in Rochette and Janzen (2005), and by Zhong et al. (2011). While Lemke et al. (2007) and Zhong et al. (2011) measured cumulative fluxes of $0.38-0.74 \mathrm{~kg} \mathrm{~N}^{-N_{2}} \mathrm{O} \mathrm{ha}^{-1} \mathrm{yr}^{-1}$, and $0.47-2.88{\mathrm{~kg} \mathrm{~N}-\mathrm{N}_{2}}_{2} \mathrm{Oha}^{-1}$ over the whole growing season, respectively, our estimates ranged from 0.03 to $0.9 \mathrm{~kg} \mathrm{~N}$ $\mathrm{N}_{2} \mathrm{Oha}^{-1} \mathrm{yr}^{-1}$ over the growing season (Table 3).

The total $\mathrm{N}$ in crop residues and in soil after harvest was similar or larger for the pea crop than for the other fertilized crops. However, the $\mathrm{N}_{2} \mathrm{O}$ emissions resulting from residue decomposition, as estimated from measurements between harvest and the next crop, did not differ significantly between the three crops. This shows that the pea residues are not a larger $\mathrm{N}_{2} \mathrm{O}$ source than wheat/rapeseed residues. It also means that the other possible source of $\mathrm{N}_{2} \mathrm{O}$ in a pea crop, $\mathrm{N}$-rich root exudates, did not add significant emissions, while the contribution of roots to the soil $\mathrm{N}$ pool has been shown to reach $22-25 \%$ of the total plant $\mathrm{N}$ at maturity (Mahieu et al., 2007). We therefore assume that there were no subsequent effects of the pea crop to suggest that this crop is a larger or smaller $\mathrm{N}_{2} \mathrm{O}$ emitter than a cereal or an oilseed crop.

All these observations support the opinion of Rochette and Janzen (2005), agreed by IPCC (2006), that BNF should not be considered as a $\mathrm{N}_{2} \mathrm{O}$ source in the $\mathrm{N}_{2} \mathrm{O}$ emission inventory and that $\mathrm{N}_{2} \mathrm{O}$ emission from legumes is much lower than according to IPCC (1996).

\subsection{Assessment of $\mathrm{N}_{2} \mathrm{O}$ emissions for three years of a crop succession}

Our measurements could be converted to a single year to calculate the $\mathrm{N}_{2} \mathrm{O}$ emissions of cropping systems over crop successions. We thus compared different rotations, with or without a pea crop, which are considered as possible agronomic options in France. This included a classical rape/wheat/wheat rotation, taken as reference, a pea/wheat/wheat and a wheat/pea/rape rotation for assessing the effect of including a pea crop and a pea/unfertilized wheat/wheat to create a rotation where the $\mathrm{N}$ fixed by the legume crop could be profitable to the next crop. The comparison with the reference rotation showed that including a pea crop in the three-year rotation leads to a significant $20-25 \%$ reduction in GHG emissions at the rotation scale. This value is consistent with the $14 \%$ reduction of GHG emissions for a $20 \%$ introduction of pea into rotations calculated by Nemecek et al. (2008) through Life Cycle Assessments. The rotation with both peas and unfertilized wheat led to a reduction of $50 \%$ in $\mathrm{N}_{2} \mathrm{O}$ emissions. Including a pea crop could thus contribute significantly to improve the GHG budget of agricultural systems. However, this does not consider the economic balance of the rotation.

\section{Conclusions}

These data clearly showed the potential of a pea crop to reduce $\mathrm{N}_{2} \mathrm{O}$ emissions in cropping systems. This has been assessed at the crop lifespan and annual scales (including catch crops) and rotation scale. These results should be confirmed in other conditions, particularly on other soil types, as our experiment was done on a low-emitting soil. Moreover, in order to avoid underestimates due to infrequent sampling and to be sure of capturing emission pulses, it would be better to measure $\mathrm{N}_{2} \mathrm{O}$ fluxes by using automated chambers or to model daily fluxes. Models simulating $\mathrm{N}_{2} \mathrm{O}$ fluxes are currently being improved and made more precise and their predictive quality can be improved by calibration with real data (Lehuger et al., 2009).

Besides reducing GHG emissions during crop growth, the reduction of the GHG budget of a pea crop is also linked to the reduced consumption of GHG (esp. $\mathrm{CO}_{2}$ from fossil fuels) due to production and transport needed to manufacture nitrogen fertilizer, which is not applied on the pea crop, and whose rate is reduced on the following crop (Nemecek et al., 2008). According to our results, showing a reduction in the $\mathrm{N}_{2} \mathrm{O}$ emissions during the pea crop of $75-80 \%$ compared with a fertilized crop, the overall savings in GHG emissions could reach $2.5 \mathrm{teq} \mathrm{CO}_{2} \mathrm{ha}^{-1}$ (T. Nemecek, personal communication, 2011).

Acknowledgements. This work was supported by grants from CASDAR 7-175. We acknowledge the technical team of UMR Agronomie for assistance during the experiment and the support of the INRA Experimental Unit of Versailles-Grignon for managing the trial.

Edited by: A. R. Mosier

\section{References}

Bates, D. and Maechler, M.: lme4: Linear mixed-effects models using S4 classes, http://CRAN.R-project.org/package=lme4, 2009.

Carrouée, B., Bourgeais, E., and Aveline, A.: Nitrate leaching related to dry pea in arable crop rotations, in: Grain legumes and the environment: how to assess benefits and impacts?, edited by: AEP-Paris, 117-124, 2006.

Crutzen, P. J. and Ehhalt, D. H.: Effects of nitrogen fertilizers and combustion on the stratospheric ozone layer, Ambio, 6, 112-117, 1977.

Crutzen, P. J., Mosier, A. R., Smith, K. A., and Winiwarter, W.: $\mathrm{N}_{2} \mathrm{O}$ release from agro-biofuel production negates global warming reduction by replacing fossil fuels, Atmos. Chem. Phys., 8, 389-395, doi:10.5194/acp-8-389-2008, 2008.

Davidson, E. A.: The contribution of manure and fertilizer nitrogen to atmospheric nitrous oxide since 1860 , Nat. Geosci., 2, 659662, 2009.

Duxbury, J. M., Bouldin, D. R., Terry, R. E., and Tate, R. L.: Emissions of nitrous oxide from soils, Nature, 298, 462-464, 1982. 
Firestone, M. K. and Davidson, E. A.: Microbiological basis of $\mathrm{NO}$ and $\mathrm{N}_{2} \mathrm{O}$ production and consumption in soil, in: Exchange of Trace Gases Between Terrestrial Ecosystems and the Atmosphere, edited by: Andreae, M. O. and Schimel, D. S., Wiley, 721 pp., 1989.

Hénault, C. and Revellin, C.: Inoculants of leguminous crops for mitigating soil emissions of the greenhouse gas nitrous oxide, Plant Soil, 346, 289-296, 2011.

Hénault, C., Devis, X., Page, S., Justes, E., Reau, R., and Germon, J. C.: Nitrous oxide emission under different soil and land management conditions, Biol. Fertil. Soils, 26, 199-207, 1998

Hothorn, T., Bretz, F., and Westfall, P.: Simultaneous Inference in General Parametric Models, Biometrical J., 50, 346-363, 2008.

Hauggaard-Nielsen, H., Ambus, P., and Jensen, E. S.: The comparison of nitrogen use and leaching in sole cropped versus intercropped pea and barley, Nutr. Cycl. Agroecosys., 65, 289-300, doi:10.1023/A:1022612528161, 2003.

Hutchinson, G. L. and Livingston, G. P.: Use of chamber systems to measure trace gas fluxes, in: Agricultural Ecosystem Effects on Trace Gases and Global Climate Change, edited by: Harper, L. A., Mosier, A. R., Duxburry, J. M., and Rolston, D. E., ASA Special Publication 55, ASA, CSSA, SSSA, Madison, WI, 6378, 1993.

IPCC: Revised 1996 IPCC Guidelines for National Greenhouse Gas Inventories, edited by: Houghton, J. T., Meira Filho, L. G., Lim, B., Treanton, K., Mamaty, I., Bonduki, Y., Griggs, D. J., and Callender, B. A., IPCC/OECD/IEA, UK Meteorological Office, Bracknell, 1996.

IPCC 2006: IPCC Guidelines for National Greenhouse Gas Inventories, Prepared by the National Greenhouse Gas Inventories Programme, edited by: Eggleston, H. S., Buendia, L., Miwa, K., Ngara, T., and Tanabe, K., IGES, Japan, 2006.

IPCC: Climate Change 2007: The Fourth Assessment Report (AR4) edited by: Salomon, S., Quin, D., Manning, M., and Chen, Z., Cambridge University Press, Vol II The Physical Science Basis, 996 pp., 2007

Jensen, E. S. and Hauggaard-Nielsen, H.: How can increased use of biological $\mathrm{N}_{2}$ fixation in agriculture benefit the environment?, Plant Soil, 252, 177-186, 2003.

Lehuger, S., Gabrielle, B., Van Oijen, M., Makowski, D., Germon, J. C., Morvan, T., and Hénault, C.: Bayesian calibration of the nitrous oxide emission module of an agroecosystem model, Agr. Ecosyst. Environ., 133, 208-222, doi:10.1016/j.agee.2009.04.022, 2009.

Loubet, B., Laville, P., Lehuger, S., Larmanou, E., Fléchard, C., Mascher, N., Génermont, S., Roche, R., Ferrara, R. M., Stella, P., Personne, E., Durand, B., Decuq, C., Flura, D., Masson, S., Fanucci, O., Rampon, J. N., Siemens, J., Kindler, R., Gabrielle, B., Schrumpf, M., and Cellier, P.: Carbon, nitrogen and Greenhouse gases budgets over a four years crop rotation in northern France, Plant Soil, 343, 109-137. doi:10.1007/s11104-0110751-9, 2011.

Laville, P., Lehuger, S., Loubet, B., Chaumartin, F., and Cellier, P.: Effect of management, climate and soil conditions on $\mathrm{N}_{2} \mathrm{O}$ and $\mathrm{NO}$ emissions from an arable crop rotation using high temporal resolution measurements, Agr. Forest Meteorol., 151, 228-240, doi:10.1016/j.agrformet.2010.10.008, 2011.
Le Cadre, E.: Modélisation de la volatilisation d'ammoniac en interaction avec les processus chimiques et biologiques du sol, Thèse INA P-G, Paris, 30 March 2004, 211 pp., 2004.

Leip, A., Achermann, B., Billen, G., Bleeker, A., Bouwman, A. F., de Vries, A., Dragosits, U., Doring, U., Fernall, D., Geupel, M., Herolstab, J., Johnes, P., Le Gall, A. C., Monni, S., Neveceral, R., Orlandini, L., Prud'homme, M., Reuter, H. I., Simpson, D., Seufert, G., Spranger, T., Sutton, M. A., van Aardenne, J., Vos, M., and Winiwarter, W.: Integrating nitrogen fluxes at the European scale, in: The European Nitrogen Assessment, Sources, Effects and Polilicy Perspectives, edited by: Sutton, M. A., Howard, C. M., Erisman, J. W., Billen, G., Bleeker, A., Grennfelt, P., van Grinsven, H., and Grizzeti, B., Cambridge, Cambridge University Press, 345-376, 2011.

Lemke, R. L., Zhong, Z., Campbell, C. A., and Zentner, R.: Can Pulse Crops Play a Role in Mitigating Greenhouse Gases from North American Agriculture?, Agronom. J., 99, 1719-1725, doi:10.2134/agronj2006.0327s, 2007.

Mahieu, S., Fustec, J., Faure, M. L., Corre-Hellou, G., and Crozat, Y.: Comparison of two ${ }^{15} \mathrm{~N}$ labelling methods for assessing nitrogen rhizodeposition of pea, Plant Soil, 295, 193-205, 2007.

Nemecek, T., von Richthofen, J.-S., Dubois, G., Casta, P., Charles, R., and Pahl, H.: Environmental impacts of introducing grain legumes into European crop rotations, Eur. J. Agron., 28, 380393, 2008.

Parkin, T. B.: Effect of Sampling Frequency on Estimates of $\mathrm{Cu}-$ mulative Nitrous Oxide emissions, J. Environ. Qual., 37, 13901395, doi:10.2134/jeq2007.0333, 2008.

Philibert, A., Loyce, C., and Makowski, D.: Assessment of the quality of meta-analysis in agronomy, Agr. Ecosyst. Environ., 148, 72-82, 2012.

Rochette, P. and Janzen, H.: Towards a revised coefficient for estimating $\mathrm{N}_{2} \mathrm{O}$ emissions from legumes, Nutr. Cycl. Agroecosyst., 73, 171-179, 2005.

Skiba, U. and Smith, K. A.: The control of nitrous oxide emissions from agricultural and natural soils, Chemosphere - Glob. Change Sci., 2, 379-386, 2000.

Smith, K. A. and Dobbie, K. E.: The impact of sampling frequency and sampling times on chamber-based measurements of $\mathrm{N}_{2} \mathrm{O}$ emissions from fertilized soils, Glob. Change Biol., 7, 933-945, 2001.

Stehfest, E. and Bouwmann, A.: $\mathrm{N}_{2} \mathrm{O}$ and $\mathrm{NO}$ emission from agricultural fields and soils under natural vegetation: summarizing available measurement data and modeling of global annual emissions, Nutr. Cycl. Agroecosys., 74, 207-228, doi:10.1007/s10705-006-9000-7, 2006

Velthof, G. L. and Oenema, O.: Nitrous oxide emission from dairy farming systems in the Netherlands, Neth. J. Agric. Sci., 45, 347360, 1997.

Zhong, Z., Lemke, R. L., and Nelson, L. M.: Nitrous oxide emissions associated with nitrogen fixation by grain legumes, Soil Biol. Biochem., 41, 2283-2291, doi:10.1016/j.soilbio.2009.08.009, 2009.

Zhong Z., Nelson L. M., and Lemke R. L.: Nitrous oxide emissions from grain legumes as affected by wetting/drying cycles and crop residues, Biol. Fertil. Soils, 47, 687-699, 2011. 